GLOBAL WATER PATHOGEN PROJECT

PART FIVE. CASE STUDIES

\title{
WASTEWATER REUSE IN AGRICULTURE AND HEALTH RISK IN VIETNAM
}

\section{Hung Nguyen-Viet}

International Livestock Research Institute

Center for Public Health and Ecosystem Research - Hanoi University of Public Health Hanoi, Vietnam

\section{Phuc Pham-Duc}

Center for Public Health and Ecosystem Research - Hanoi University of Public Health Hanoi, Vietnam 


\section{Copyright:}

\section{cc) (1) (2) \\ BY SA}

This publication is available in Open Access under the Attribution-ShareAlike 3.0 IGO (CC-BY-SA 3.0 IGO) license (http://creativecommons.org/licenses/by-sa/3.0/igo). By using the content of this publication, the users accept to be bound by the terms of use of the UNESCO Open Access Repository (http://www.unesco.org/openaccess/terms-use-ccbysa-en).

\section{Disclaimer:}

The designations employed and the presentation of material throughout this publication do not imply the expression of any opinion whatsoever on the part of UNESCO concerning the legal status of any country, territory, city or area or of its authorities, or concerning the delimitation of its frontiers or boundaries. The ideas and opinions expressed in this publication are those of the authors; they are not necessarily those of UNESCO and do not commit the Organization.

\section{Citation:}

Nguyen-Viet, H. and Pham-Duc, P. 2019. Wastewater reuse in agriculture and health in Vietnam. In: J.B. Rose and B. Jiménez-Cisneros, (eds) Global Water Pathogen Project. http://www.waterpathogens.org (S. Petterson and G. Medema (eds) Part 5 Case Studies) http://www.waterpathogens.org/book/wastewater-reuse-inagriculture-and-health-risk-in-vietnam Michigan State University, E. Lansing, MI, UNESCO. https://doi.org/10.14321/waterpathogens.70

Acknowledgements: K.R.L. Young, Project Design editor; Website Design: Agroknow (http://www.agroknow.com)

Last published: March 19, 2019 


\section{Summary}

\section{Highlights}

The study provides a framework to estimate the health risk of farmers using wastewater in agriculture.
The study addresses the SDG 6.3: to contribute to inform water recycling and reuse.

Exposure to wastewater via contact with Nhue River water, pond water and composted excreta represents an important health risk.

Study results are useful in developing an integrated strategy for risk management in the agricultural settings.

\section{Graphical abstract}
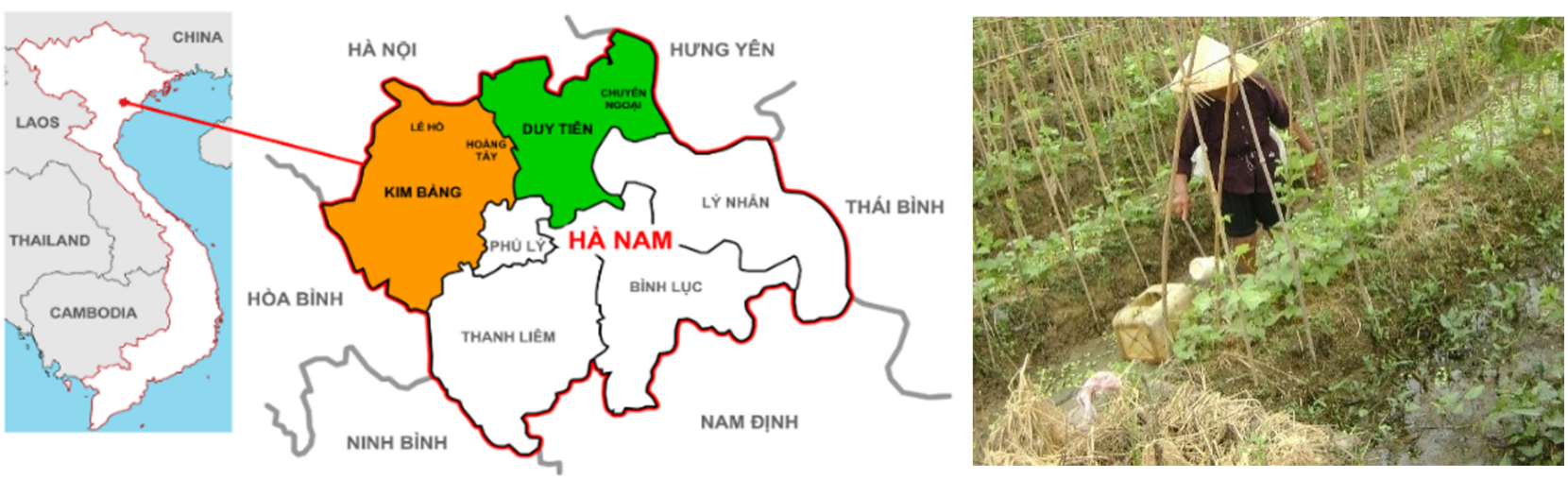

(photo provided by Hung Nguyen-Viet)

\section{Risk Management Objective}

The objective of this case study was to predict the risk of diarrhea related to the use of wastewater and excreta in an agricultural community in Vietnam. We aimed to assess the risk, and to recommed how farmers can reduce the risk when using wastewater and hence to promote the safe use of wastewater.

\section{Location and Setting}

In Vietnam, the reuse of wastewater and human excreta for agriculture is popular. Due to poor treatment of wastewater and excreta before use, health risk posed by reuse activities might be important. This study was conducted in Ha Nam province where wastewater come from Hanoi city to the Nhue river and from locally generated from agriculture and household activities. Local people use thise wastewater for agricultural activities.

\section{Description of the System}

The study was carried out in two communities of 26,000 people for 4,200 household in Ha Nam Province. The economic basis of these communities relies on both livestock and crops. The residential areas are in the vicinity of fields used for rice cultivation, vegetable planting, and fish breeding. The rice fields and local ponds cover about $50 \%$ of the surface. Most of the households have decentrilised sanitation system (septic tank, double vault latrines) to treat human and animal waste, which is reused for agriculture as fertiliser. Wastewater both from Hanoi and Ha Nam is used for irrigation. While the wastewater reuse provides many benefits, it might cause health risks for people. 


\section{Outcome and Recommendations}

- The highest load of diarrhegenic E. coli (DEC) $(6.4 \mathrm{x}$ $10^{8} \mathrm{MPN} / 100 \mathrm{ml}$ ) and C. parvum (6 oocysts $/ 100 \mathrm{ml}$ ) was in household sewage; whereas G. lamblia was highest in composted excreta (120 cysts/gram).

- The most hazardous exposures included direct contact with the Nhue River and pond water and composted excreta during field work.

- Exposure to wastewater represents an important health risk, in particular for rice production.

- Risk mitigation should focus on exposure reduction including raising the awareness of farmers and the use of personal protection equipment.

- Treatment of wastewater at the source to improve water quality is needed for long term intervention

\section{Introduction}

The use of excreta in both agriculture and aquaculture has been practised for centuries in Asia, in particular, in China and Vietnam. Wastewater and excreta reuse provides many benefits for agricultural users such as reliable water resources, valuable nutrients, increased productivity and reduction in inorganic fertilisaers, however these practises may pose potential health risks (van der Hoek et al., 2002; Raschid-Sally et al. 2005).

The study was carried out in Nhat Tan and Hoang Tay Communes, King Bang district, Ha Nam province, Northern Vietnam, situated about $60 \mathrm{~km}$ south of Hanoi (see Figure 1). Ha Nam is located at the Red River Delta with a climate characterized by a tropical monsoon. Nhat Tan and Hoang Tay communes have populations of 10,500 (2,708 households) and 5,678 (1,574 households), respectively. Most households raise livestock in their compounds. The residential areas are in the vicinity of fields used for rice cultivation, vegetable planting and fish breeding. Hoang Tay commune boarders the Nhue River and the Nhat Tan commune is connected with Nhue River through a pump station and canal system.

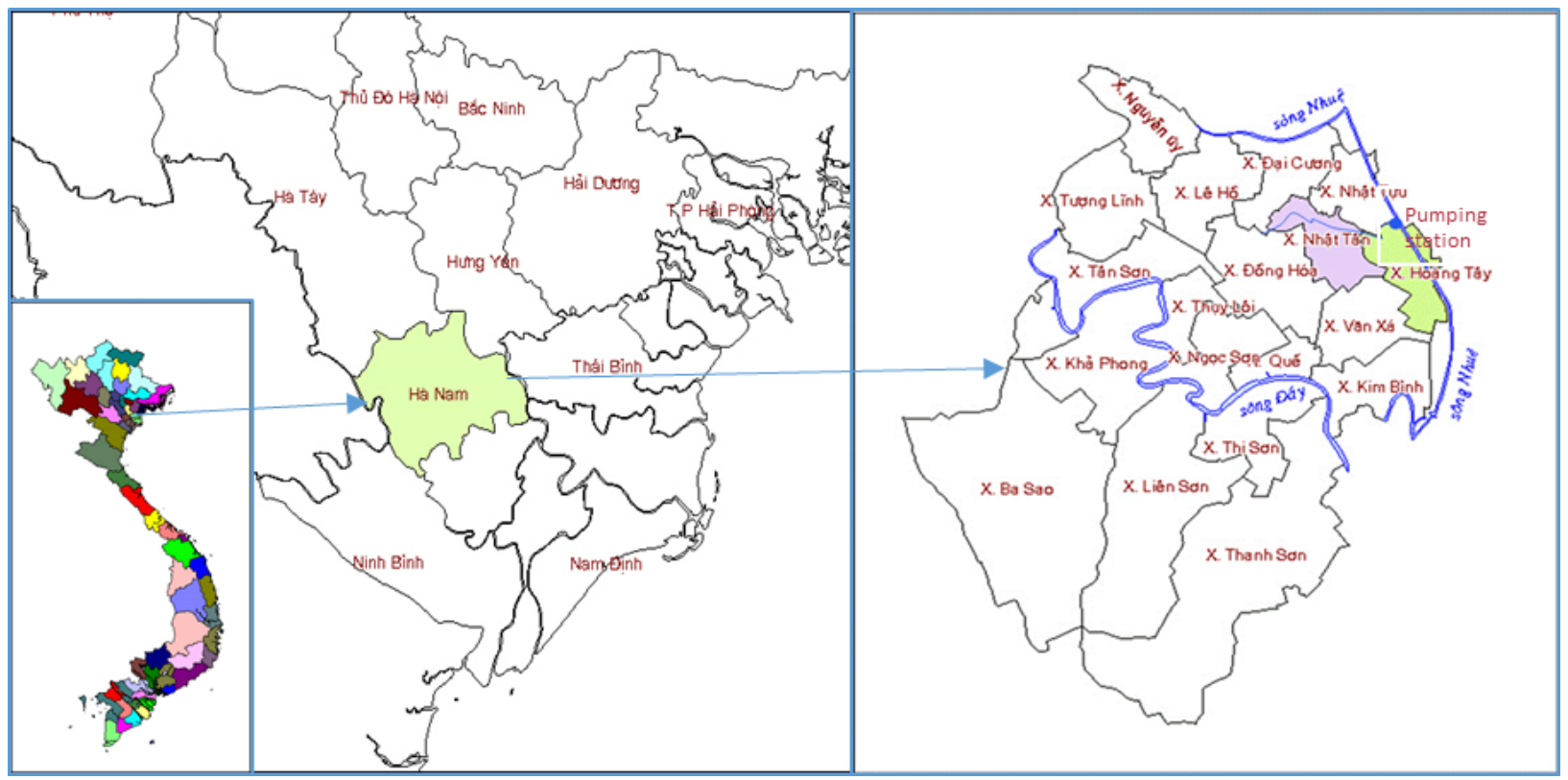

Figure 1. Map of the study sites in Hoang Tay and Nhat Tan communes, Ha Nam provice, northern Vietnam. 
Nhue River receives Hanoi's wastewater originating from households, industry, and other sources such as hospitals, without any treatment. The Nhue River water is used for crop irrigation and to feed fish ponds. Several pumping stations are located along the river and a system of open and closed canals distribute the water to fields and fish ponds. Wastewater from households (grey water from kitchens and bathrooms, and effluent from spetic tanks and sanitation facilities) is directly discharged into the small irrigation canal. The area has two main rice production cycles per year. In general, uncomposted or partially composted human and animal excreta are used as fertiliser. Personal protective measure to prevent contamination are often lacking.

The objective of this study was to assess the microbial infection risk for diarrhoeal diseases related to the use of wastewater and excreta in agriculture by Quantitative Microbial Risk Assessment (QMRA). We aimed to identify the major exposure points for disease transmission as places for public health control interventions in agricultural settings where wastewater and excreta are intensively used as irrigation water sources and fertilizers.

\section{Problem Formulation}

Hazard identification: Three reference pathogens were selected for this study: Escherichia coli 0157:H7; Giardia lamblia, and Cryptosporidium parvum. All of these pathogens have caused waterborne disease and are important pathogens in Vietnam.

Exposure pathways:Five exposure points were modelled in the assessment for accidental ingestion of Nhue River water when harvesting vegetables, involuntary ingestion of sewage when cleaning the household sewerage system, involuntary ingestion of local pond water while fishing, accidental ingestion of irrigation water used for rice; and involuntary ingestion of composted excreta when fertilising fields.

Health outcome: risk of infection with each reference pathogen

\section{Exposure Assessment}

Source:173 wastewater and excreta samples were collected monthly from 5 sampling points: (i) the Nhue River (36) (ii) household sewage (36), (iii) local ponds (36), (iv) irrigation systems (60) and (v) excreta composts (5), Each sample was analysed for E. coli; Cryptosporidium spp. and Giardia sp. The results are summarised in Table 1. For the QMRA, the concentration of E.coli 0157:H7 was assumed to be $8 \%$ of total E. coli (Haas et al., 1999; Howard et al., 2006) 
Table 1. Arithmetic mean and range of concentrations in source samples

\begin{tabular}{|c|c|c|c|c|}
\hline \multirow{2}{*}{ Exposure points } & \multirow{2}{*}{ Pathogens } & \multicolumn{3}{|c|}{ Concentrations (org.100mL-1) } \\
\hline & & Arithmetic mean & Min & Max \\
\hline \multirow{3}{*}{ Nhue River water } & Giardia sp. & 6.9 & 0 & 76 \\
\hline & Cryptosporidium spp. & 5.8 & 0 & 61 \\
\hline & E. coli & $1.12 \mathrm{E}+06$ & 78 & $1.14 \mathrm{E}+07$ \\
\hline \multirow{3}{*}{ Household sewage } & Giardia sp. & 28.9 & 0 & 310 \\
\hline & Cryptosporidium spp. & 30.8 & 0 & 295 \\
\hline & E. coli & $6.37 \mathrm{E}+08$ & $5.13 \mathrm{E}+04$ & $2.15 \mathrm{E}+09$ \\
\hline \multirow{3}{*}{ Local pond water } & Giardia sp. & 3.9 & 0 & 43 \\
\hline & Cryptosporidium spp. & 2.2 & 0 & 32 \\
\hline & E. coli & $4.27 \mathrm{E}+06$ & 23 & $4.01 \mathrm{E}+07$ \\
\hline \multirow{3}{*}{ Irrigation system } & Giardia sp. & 9.7 & 0 & 125 \\
\hline & Cryptosporidium spp. & 1 & 0 & 17 \\
\hline & E. coli & $1.93 \mathrm{E}+06$ & 180 & $2.10 \mathrm{E}+07$ \\
\hline \multirow{3}{*}{ Composted excreta } & Giardia sp. & 120 & 0 & 1561 \\
\hline & Cryptosporidium spp. & 0 & 0 & 0 \\
\hline & E. coli & $2.19 \mathrm{E}+05$ & 14 & $2.06 \mathrm{E}+06$ \\
\hline
\end{tabular}

Controls: No control measures were modelled in the QMRA

Exposures: A field survey was carried out from April to August 2009 in Hoang Tay and Nhat Tan communes. There were 235 adults (male and femail) ranging from 16 to 65 in age, randomly selected from the household list provided by the Communal People's Committee. A structured questionnaire was used to obtain information to assess people's exposure to the Nhue River water, local ponds, and irrigation water, as well as exposure to human and animal excreta at home and in the fields. The magnitude and frequency of exposure for each modelled event is summarised in Table 2.

Table 2. Accidental ingestion at each exposure point (scenario) and dose assumptions

\begin{tabular}{lcc}
\hline \multicolumn{1}{c}{ Exposure Points } & Events & Ingestion Dose of Water \\
\cline { 2 - 3 } Nhue River water & Harvesting vegetable in Nhue & $10 \mathrm{ml}$ per event \\
Household sewage & River & 180 events per year \\
& Cleaning household sewage & $10 \mathrm{~mL}$ per event \\
Local ponds & Fishing in the local ponds & 8 events per year \\
& & $100 \mathrm{~mL}$ per event \\
Irrigation system & Growing rice & 72 events per year \\
& & $10 \mathrm{~mL}$ per event \\
Composted excreta & Application of excreta in the & 58 events per year
\end{tabular}




\section{Health Effects Assessment}

The assumptions applied in the health etffects assessment are summarised in Table 3 .

Table 3. Dose-response models and morbidity assumptions for the health effects assessment

\begin{tabular}{|c|c|c|c|c|c|}
\hline \multirow[b]{2}{*}{ Reference Pathogen } & \multicolumn{3}{|c|}{ Dose-Response Model } & \multicolumn{2}{|c|}{ Morbidity } \\
\hline & Model & $\begin{array}{c}\text { Parameter } \\
\text { Values }\end{array}$ & Reference & $\begin{array}{c}\text { Probability } \\
\text { Illness } \\
\text { Given } \\
\text { Infection } \\
\end{array}$ & Reference \\
\hline E. coli 0157:H7 & $\begin{array}{l}\text { Beta Poisson } \\
\text { approximation }\end{array}$ & $\begin{array}{c}\mathrm{a}=0.1778 ; \\
\mathrm{ID} 50=8.60 \mathrm{E}+ \\
07\end{array}$ & $\begin{array}{l}\text { Haas et } \\
\text { al., } 1999\end{array}$ & 0.25 & $\begin{array}{l}\text { Howard et } \\
\text { al., } 2006\end{array}$ \\
\hline Giardia lamblia & Exponential & $r=0.0198$ & $\begin{array}{c}\text { Rose et al., } \\
\text { 1991; } \\
\text { Haas et } \\
\text { al., } 1996\end{array}$ & 0.67 & $\begin{array}{c}\text { Rose et al., } \\
1991\end{array}$ \\
\hline Cryptosporidium parvum & Exponential & $r=0.00467$ & $\begin{array}{c}\text { Rose et al., } \\
1991 ; \\
\text { Haas et } \\
\text { al., } 1996\end{array}$ & 0.39 & $\begin{array}{l}\text { Haas et } \\
\text { al., } 1999\end{array}$ \\
\hline
\end{tabular}

\section{Risk Characterization}

The annual risk of infection was calculated for each . scenario, and is summarised by pathogen and exposure in Figure 2

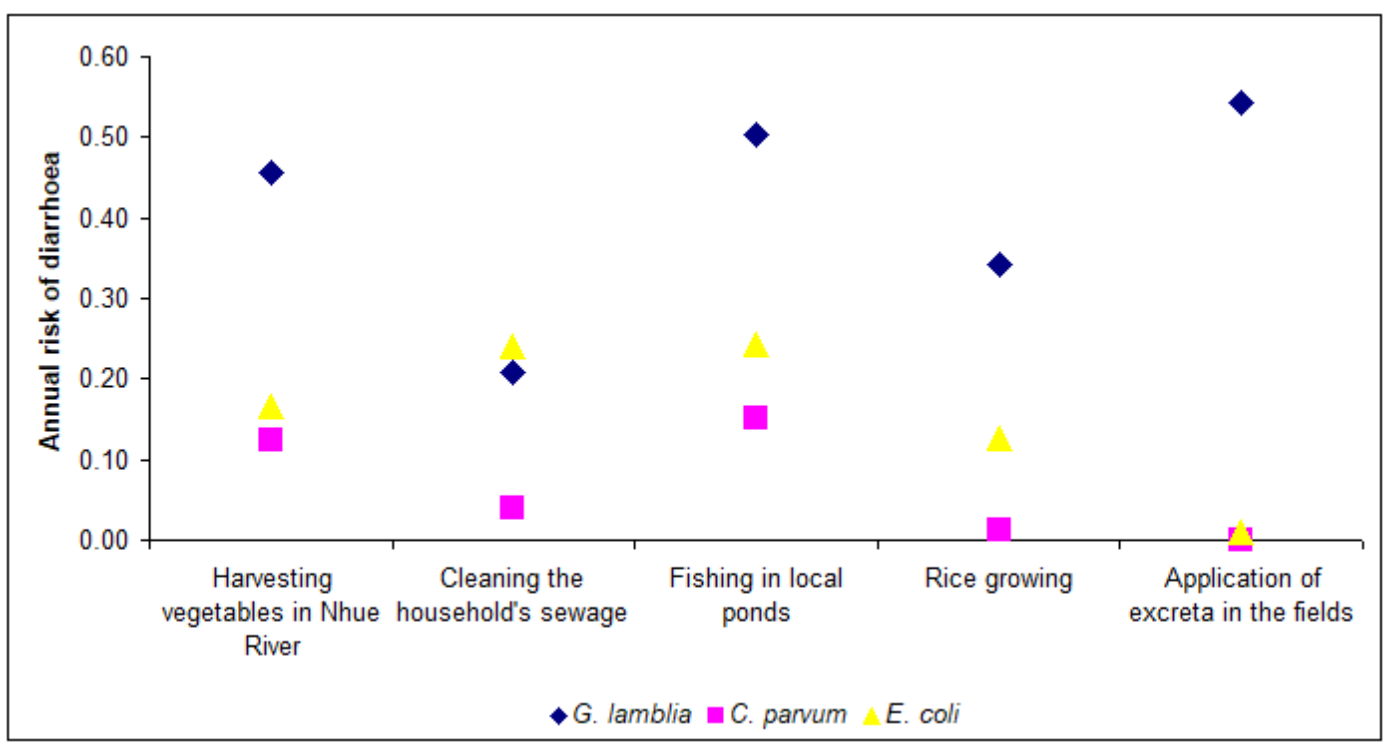

Figure 2. Annual risk of diarrhoeal diseases by reference pathogen and exposure scenario

\section{Risk Management}

The assessment indicated that risks are unacceptably high for G. lamblia, C. parvum and diarrhegenic E. coli infections among people exposed to wastewater and excreta. Study results are useful in developing an integrated strategy for pathogen management and public health control measures in the agricultural settings where wastewater and excreta are intensively used as irrigation water sources and fertilisers; and where household wastewater is freely discharged into irrigation systems. 


\section{References}

Haas, C.N., Rose, J.B. and Gerba, C.P. (1999). Quantitative Microbial Risk Assessment. John Wiley and Sons, Inc. New York. pp. 449.

Howard, G., Pedley, S. and Tibatemwa, S. (2006). Quantitative microbial risk assessment to estimate health risks attributable to water supply: can the technique be applied in developing countries with limited data?. Journal of Water and Health. 4, pp. 49-65.

Raschid-Sally, L., Carr, R.M. and Buechler, S. (2005). Managing wastewater agriculture to improve livelihoods and environmental quality in poor countries. Irrigation and Drainage. 54, pp. 11-22. doi: 10.1002/ird.182.

Rose, J.B., Haas, C.N. and Regli, S. (1991). Risk assessment and control of waterborne giardiasis. American Journal of Public Health. 81, pp. 709-713.

Van Der Hoek, W., M. Hassan, U., Ensink, J.H.J., Feenstra, S., Raschid-Sally, L., Munir, S. et al. (2002). Urban wastewater: A valuable resource for agriculture - A case study from Haroonabad, Pakistan. International Water Management Institute (IWMI). Columbo. 